\title{
Geotechnical Studies of World Largest Lead-Zinc Producing- Rampura AguchaMines, Bhilwara District, Rajasthan
}

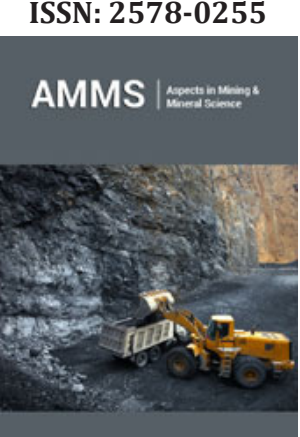

*Corresponding author: Jamuna Biswa, Department of Geology, MohanLalSukhadia University, Udaipur Rajasthan

Submission: 眥 May 01, 2020

Published: 際January 22, 2021

Volume 6 - Issue 1

How to cite this article: Jamuna Biswa, Ganga Biswa, Mukesh Bhakar, Geotechnical Studies of World Largest Lead-Zinc Producing- Rampura AguchaMines, Bhilwara District, Rajasthan. Aspects Min Miner Sci. 6(1). AMMS. 000630. 2021. DOI: 10.31031/AMMS.2021.06.000630

Copyright@ Jamuna Biswa, This article is distributed under the terms of the Creative Commons Attribution 4.0 International License, which permits unrestricted use and redistribution provided that the original author and source are credited.

\author{
Jamuna Biswa ${ }^{1 *}$, Ganga Biswa ${ }^{2}$ and Mukesh Bhakar ${ }^{3}$ \\ 1,2Department of Geology, MohanLalSukhadia University, Rajasthan \\ ${ }^{3}$ Shree Cement Limited, Chhattisgarh
}

\begin{abstract}
The Paleoproterozoic age of the Aravalli Supergroup bears most complex deposit of economically important strata bound base metal- lead and zinc. The Rampura Aguchamine which is located in the Bhilwara district of Rajasthan, NW India has a SEDEX-type of deposit with its highly deformed nature. The basement ensemble represented by the graphite-mica sillimanite gneiss shows an intricate tectonic evolutionary history. The potentially hazardous nature of this large open-pit mine requires a proper geotechnical studies for mine designing and general operating procedure to allow safe and economic mining. The inherent geotechnical complexity parameters incorporates the physical and mechanical properties like porosity, swelling,moisturecontent, degree of saturation, anisotropy, durability, elasticity, and plasticity.If appropriately analyzed, these traits can convey valuable information by using advanced techniques. Slope Stability Radar (SSR), Inclinometer, prism, piezometer, rock bolting, rock stitching have been manoeuvre to oversee the RQD, RMR, Q system and variant geological criterion.
\end{abstract}

Keywords: Aravalli supergroup; SEDEX; Slope stability radar (SSR); RQD; RMR; Q system

\section{Introduction}

The Rampura Aghucha lead zinc mineralization in the north western part of India is known for the unusual concentration of lead and zinc sulphide ores. The host rock of this SEDEX type of deposit is represented by gneiss-granite-amphibolites belonging to the Bhilwara Supergroup [1]. This Archaean Supergroup [2,3], which constitutes the basement of the Aravalli province, consists mainly of a heterogeneous complex of granites and granodioritic gneisses, migmatites, amphibolites, and granulites. It also contains huge enclaves of metavolcano sedimentary rocks [2,3]. The base metal deposits have been broadly classified as sedimentary exhalative (SEDEX)-type or volcanogenic massive sulphide (VMS)-type [4]. Major concentrations of this mineralization in the Bhilwara domain occur in the RampuraAgucha deposit and in the Pur-Banera and Bethumni-Dariba-Bhinder mineralized zones and is a world-class deposit of $\mathrm{Pb}$ - $\mathrm{Zn}$ - Ag, with the highest combined metal grade (about 15\%) of all the base-metal deposits in India. The ore minerals which is basically present in this part is Sphalerite, Galena, Pyrite, Pyrrhotite, Arsenopyrite \& other Sulpho salts and the gangue minerals which is present is Quartz, Feldspar, Graphite, Sillimanite, Mica, Gypsum \& Calcite [5]. The dominant lithological unit in this area is banded garnet biotite sillimanite schists and gneiss with or without graphite. To provide safe and economic mining in opencast mines various parameters like porosity, swelling ,moisture content, degree of saturation, anisotropy, durability, elasticity, and plasticity is necessary to take care of and if appropriately analyzed, it can convey valuable information by using advanced techniques. The main objective of this paper is to study valuable information by using advanced technique to allow safe and economic mining in opencast mines.

\section{Geology}

The geology of Rajasthan has been studied by different workers [6-16] and various major geological units and major faults and lineaments of this region is being studied. The Banded Gneissic Complex (BGC) is one of the oldest rock group in Rajasthan, forming the basement on which the sedimentary rocks of successively younger Aravalli, Raialo and Delhi Groups were deposited [17]. The metasedimentary ensemble of the Bhilwara Supergroup is bounded in the west by the gneiss- granulite belt of the Sandmata Complex, a tectonothermally reconstituted Archaen basement unit [18], and a shear zone east of Jahazpur. Age of the 
deposit is Mangalwar complex of Bhilwara super group ( $>2500$ million yrs.). The geological relationship of different rocks in this part of Aravalli Mountain is shown in the Figure 1. The Aravalli mountain range in the northwest part of India has a general NESW trend [19]. It consists of two main Proterozoic sedimentary and volcano sedimentary successions, the Aravalli Supergroup, and the Delhi Supergroup, respectively, which are bounded by the Great
Boundary Fault to the east and the Western Marginal Fault to the west and these Proterozoic successions overlies Archean granitoid basement [20], commonly referred to as Banded Gneissic Complex/ BGC [17], The minimum age of the basement rocks to be $2500 \mathrm{Ma}$ [21]. The Aravalli Supergroup, a sedimentary succession with minor volcanic flows near the base, developed as a cover sequence on the granitoid basement [20], the BGC by Heron [17].

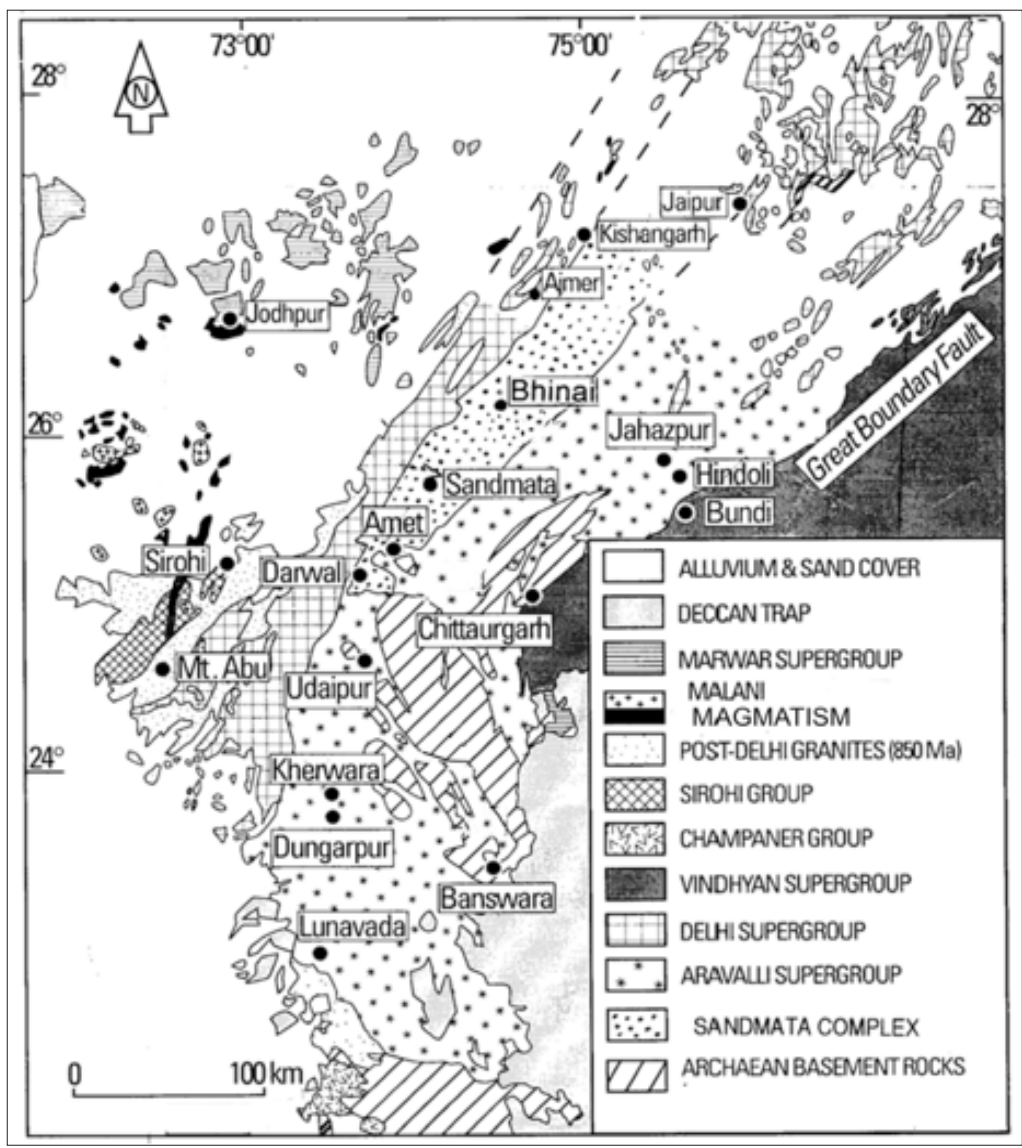

Figure 1: Generalized geological map of Aravalli Mountain belt.

\section{History of the ore body}

In Rampura Aghucha, the ore body is capped with a thin layer of gossan zone and the major minerals which is present in this ore body is sphalerite, pyrite, pyrrhotite and galena [22]. Distribution of lead and zinc in this part is quite irregular and they occur in somewhat lens shaped. The ore body is lens shaped with a maximum width of $100 \mathrm{~m}$ in the central portion and an average width of $58 \mathrm{~m}$ and extends for about $1550 \mathrm{~m}$ from S725 to N825 (Figure 2). The stratiform to stratabound nature of the base-metal deposits at Rampura-Agucha and in the Pur-Banera, BethumniDariba-Bhinder, and Zawar zones [23] specify that sedimentary environment, lithology, and stratigraphy are the primary regional controls of base-metal mineralization [23]. The Rampura-Agucha deposit, located proximal to the boundary between BGC-II and the Bhilwara Supergroup. In contrast, the Rajpura-Dariba deposit is within the Bhilwara Supergroup [24]. Graphite-mica-silimanite gneiss/schist forms the mineralization zone and the major minerals mined here are sphalerite and galena. Presences of pyrites in the deposit indicate the reducing environment condition. Some calcites and quartz veins/bands were also reported from the area [25]. The strike length is about $1500 \mathrm{~m}$, strike direction is $\mathrm{N} 50^{\circ} \mathrm{E}-\mathrm{S} 50^{\circ} \mathrm{W}$ and the dip of the ore body is $75^{\circ}-80^{\circ}$ [26]. Lithologically, the area is mainly endowed with metasediments, constituting the host rock of lead zinc sulphide deposits and granite gneiss along with calcsilicate rocks with some minor amounts of pegmatite, aplite located in certain parts of the study area. Various assessment is done to prepare mine plan, to observe the ground movement. Rampura Aghucha also uses DGPS, gyroscope (Figures 3 \& 4), which is a ground-based reference stations to broadcast the difference between the positions indicated by the satellite systems and the known fixed positions [26]. 


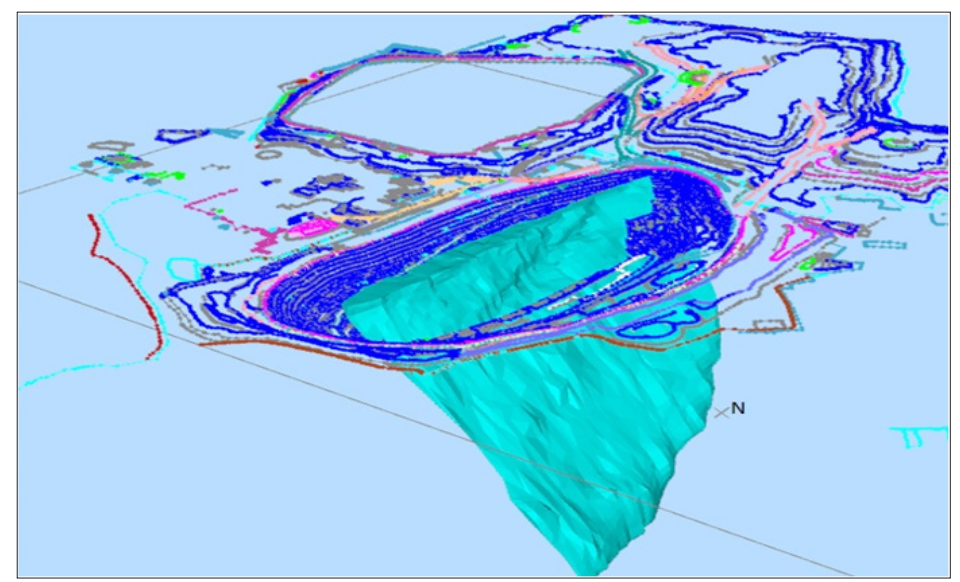

Figure 2: R A MINE (open pit).

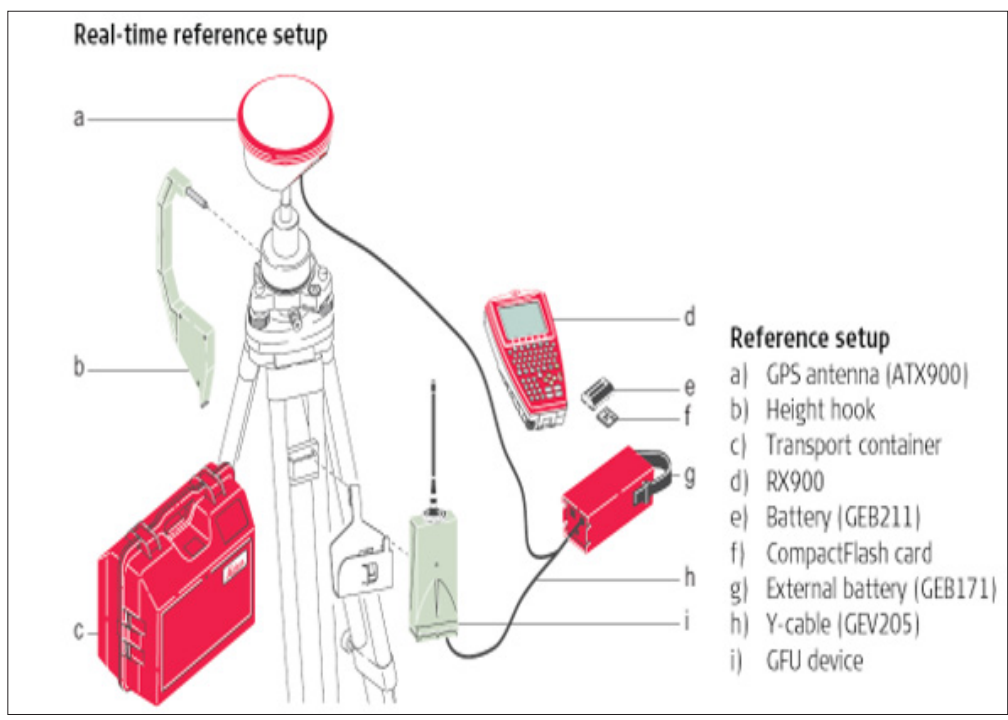

Figure 3: Gyroscope.

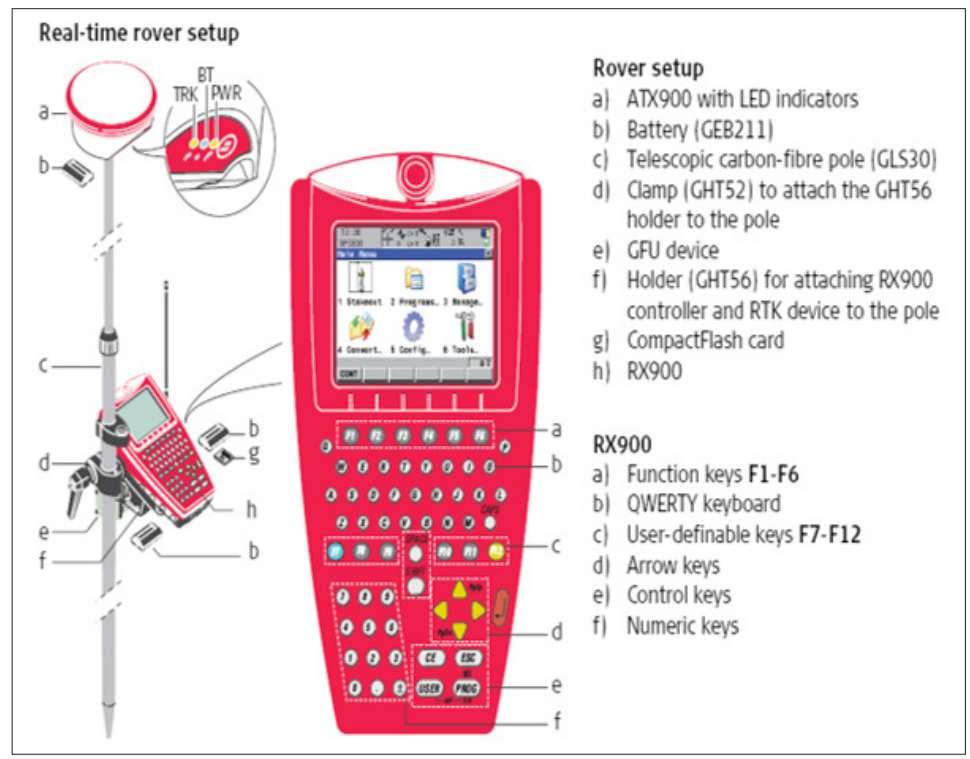

Figure 4: DGPS. 


\section{Slope Monitoring System}

For Planning of mine layouts and stoping sequences, to control blasting in haulages for improved hanging wall and sidewall control, and to ensure long-term stability, support for main excavations - pump chambers, water dams, settlers, hoist chambers and refrigeration plant chambers, rock mechanics is an important and major consideration in mines. Based on this various geotechnical tools are used to monitor various frameworks in Mines. The geological structure of this part of the area is very complicated as a result of tectonic and sedimentation processes. The long-term exploitation influenced the development of horizontal displacements. The variety of factors that have impact on the slope stability conditions, forced the necessity of complex geotechnical monitoring [27]. Slope Stability Radar, which is one of the most useful tool which helps in the management of risks. The first SSR unit to be deployed in Africa was in Novemeber 2003 on a 3 month trial [28]. It provides real time monitoring and advance warning signals before any slope or dump failure in open cast mines (Figure 5). Therefore, in order to mine deeper and steeper deposits, slope stability monitoring is an important component in any surface mine in terms of economics and safety. The likelihood of a hazardous occurrence and the severity of injury or damage to the health of people can arise from hazards at work place. In order to manage such risk at mines, various equipment used while mining and continued production which is associated with slope instability is one of the key roles of geotechnical and mining engineers in open cut mines. The SSR system can detect and alert movements of a wall with sub-millimetre accuracy, with continuity and broad area coverage. This system of monitoring help the miners without the need for mounted equipment on the wall of the strata and the radar waves adequately penetrate through rain, dust and smoke, 24 hours a day [29]. The SSR offers high precision measurement (it can measure to $\pm 0.2 \mathrm{~mm}$ of deformation under ideal conditions, completes one scan in every 2 to 15 minutes. It can scan approximately 260 degrees horizontally to 100 degrees vertically, operates in all weather conditions including dust, rain, and fog [24].

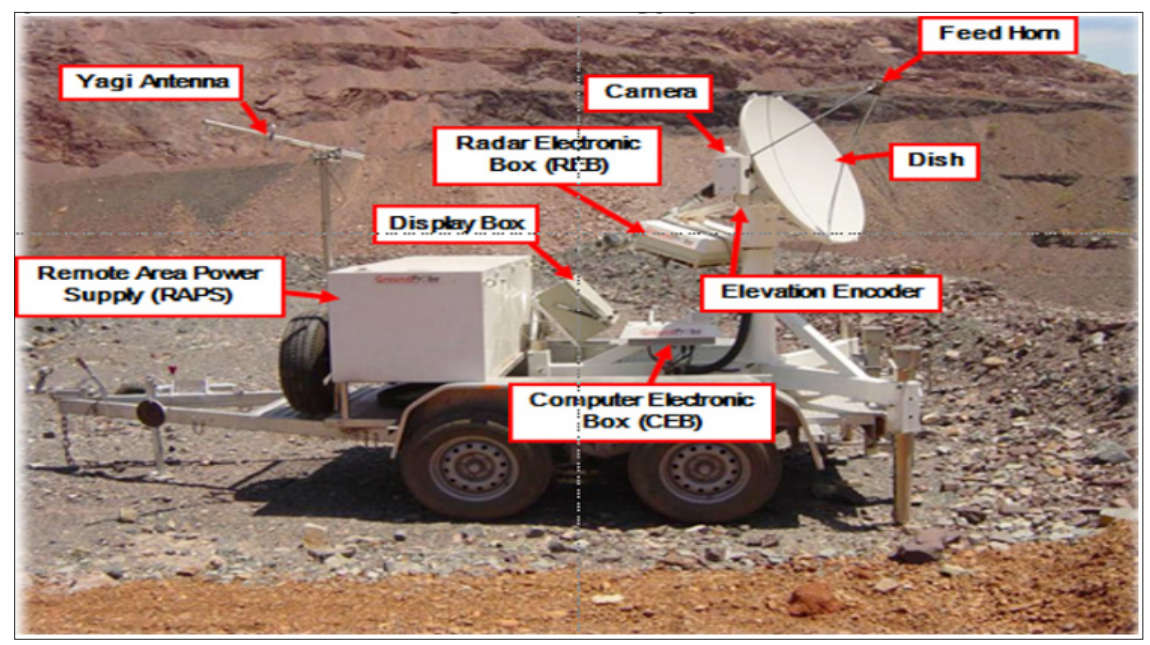

Figure 5: SSR (slope stability radar) System.

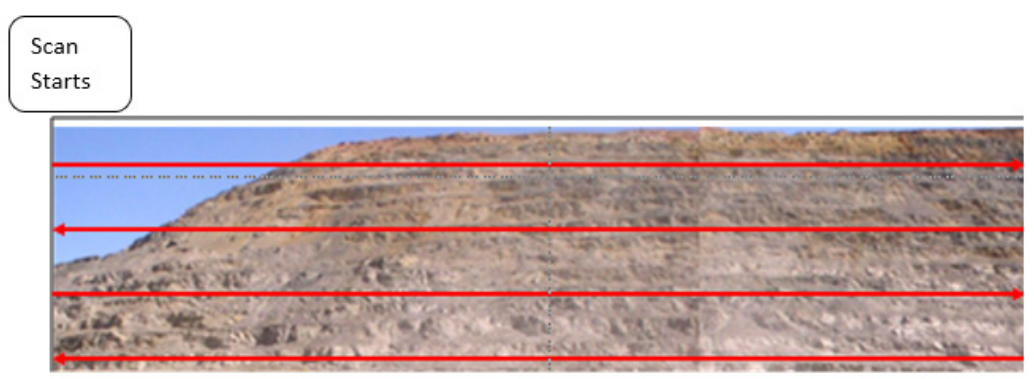

Figure 6: Scanning of slope by SSR [24]. 
The SSR scans a wall from side to side, top to bottom, emitting and receiving radar signal every 0.5 to 1 degree of rotation (Figure 6). Fault stitching method has also been used for stabilizing the faulted hangwall in Rampura Aghucha mines [29]. In this method, the $12 \mathrm{~m}$ deep $70 \mathrm{~mm}$ diameter holes are drilled into the hangwall at the spacing and burden of $2 \mathrm{~m}$ in the following pattern: A breathing pipe (12mm dia), a $13 \mathrm{~m}$ long stitching rod $(30 \mathrm{~mm}$ dia wire) and a feeder pipe (2-3ft, $18 \mathrm{~mm}$ dia) are inserted into the hole and hole is then covered (capped). Then the cemented slurry is flown through the feeder pipe into the hole and is removed from the breathing pipe (Figure 7). Different drilling and blasting techniques is used in Rampura Aghucha mines i.e
a. Presplitting
b. Using Trunk Line Delay (TLD)
c. Electronic Blasting

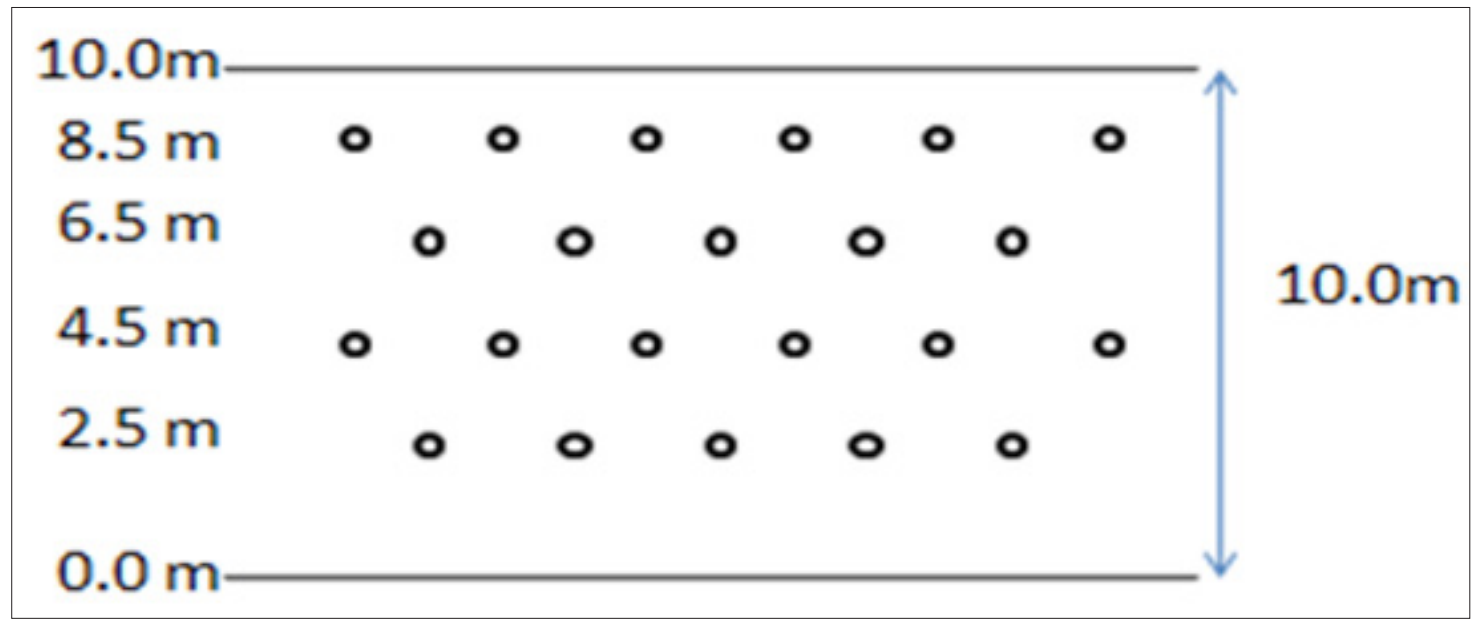

Figure 7: Patterns of Fault Stitching at hanging bench face [24].

Presplitting is basically used for controlling the blast damage to the wall by varying speed of shock wave by creating the cracks with the help of small diameter hole and light explosive and to maintain the slope angle of the bench and for the emission of gases (Figure 8). The diameter of the hole is $115 \mathrm{~mm}$, presplitting holes are done at 700 at hang wall side and 600 at footwall side. In footwall side, along with the presplit hole, a 'batter hole' is also done for better fragmentation and spacing of hole is done from 1 to $2 \mathrm{~m}$, and generally taken 8 to 12 times of hole diameter and 7 to $8 \mathrm{~kg}$ explosive cartridge is charged in one hole [26], (Figure 9).

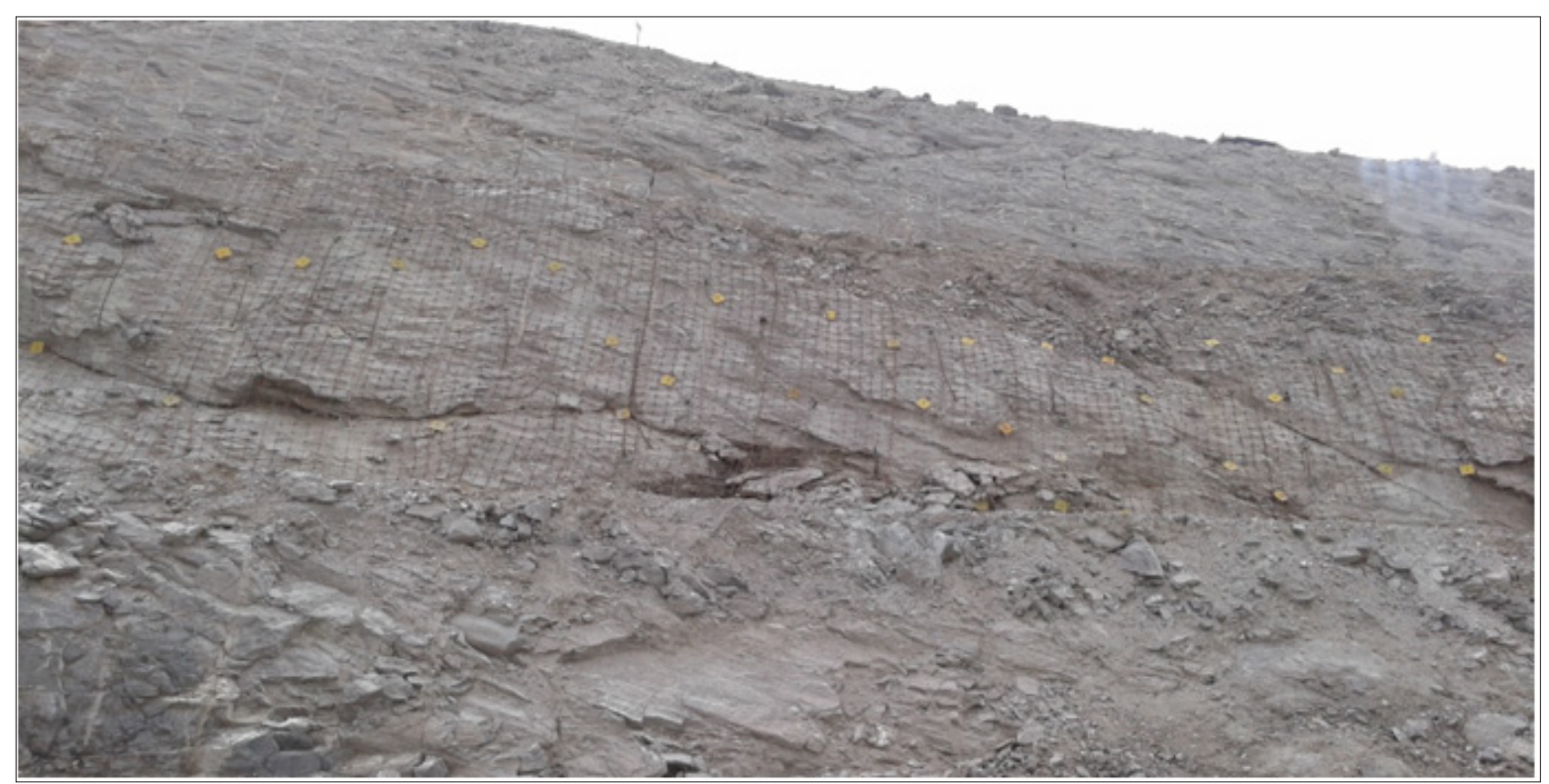

Figure 8: Fault Stitching. 


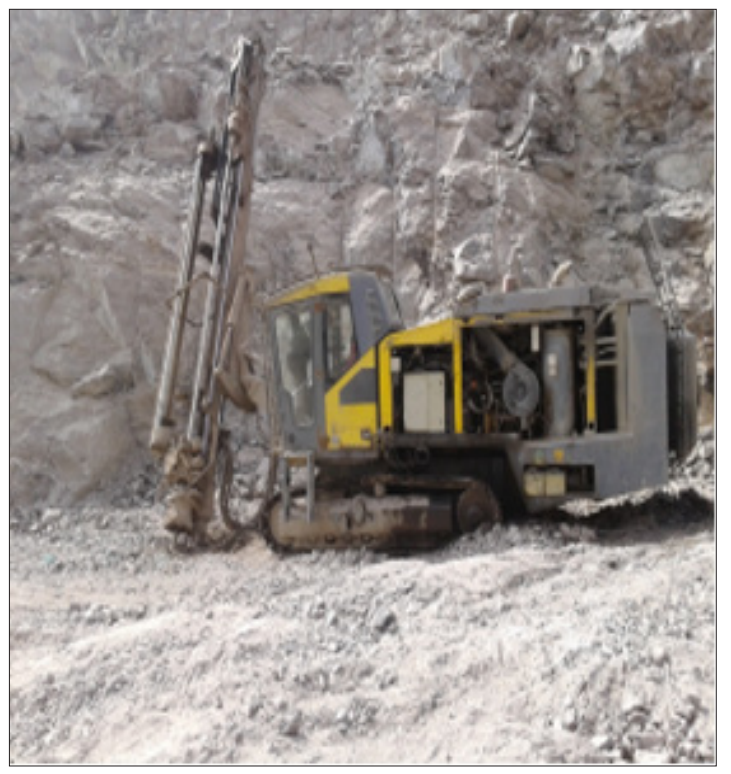

Figure 9: Presplitting.

Basically two types of delay patterns is used in surface mines of RA mines:

a. Surface delay(by trunk line delay made by ORICA explosive). Further divided in 5 types as given below:

b. $17 \mathrm{~ms}-$ yellow

c. $25 \mathrm{~ms}-\mathrm{red}$

d. $42 \mathrm{~ms}-$ white

e. $65 \mathrm{~ms}$-black

f. 100ms-blue g. Down the hole delay (with the help of primer) Nonel- $450 \mathrm{~ms}$ delay and Booster $(100 / 400 / 500 \mathrm{~g})$ with Detonator used as primer.

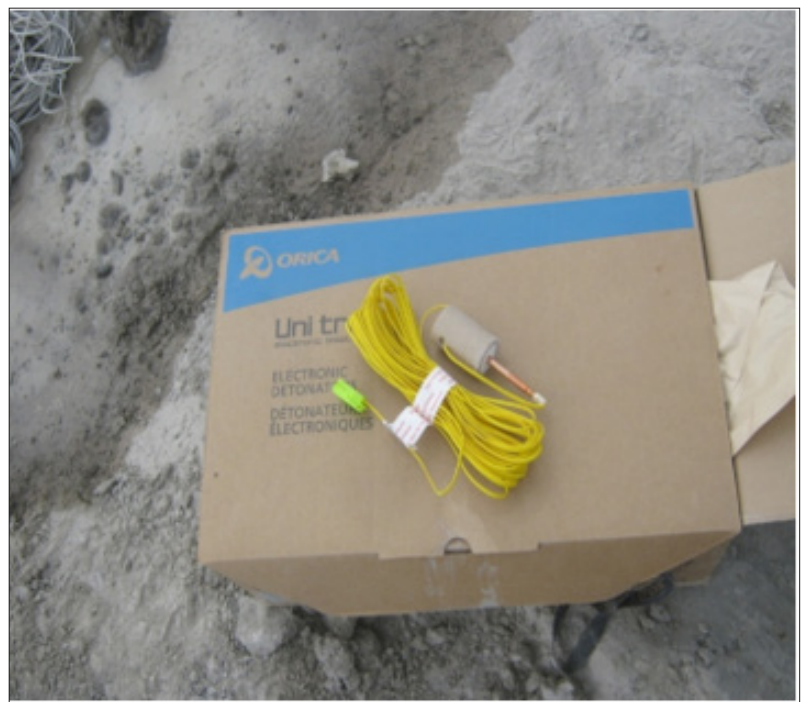

Figure 10: Electronic delay detonator.

Electronic blasting is basically use to control ground vibrations, noise and throw (fly-rock). This method is adopted where ground vibrations are needed to be limited. In RA mine, EDD blasting is used in $190 / 180 \mathrm{mRL}$ (Figure 10). Truck haulage is the most common means which is used now days for moving ore/waste in open-cast mining operations. It is used for monitoring different dumpers with the help of G.P.S. To reduce the cycle time, TDS provide proper monitoring of dumpers and to improve production and productivity in less time. TDS is mainly monitored by two components namely GPS and RADIO MEDIA (Figure 11).

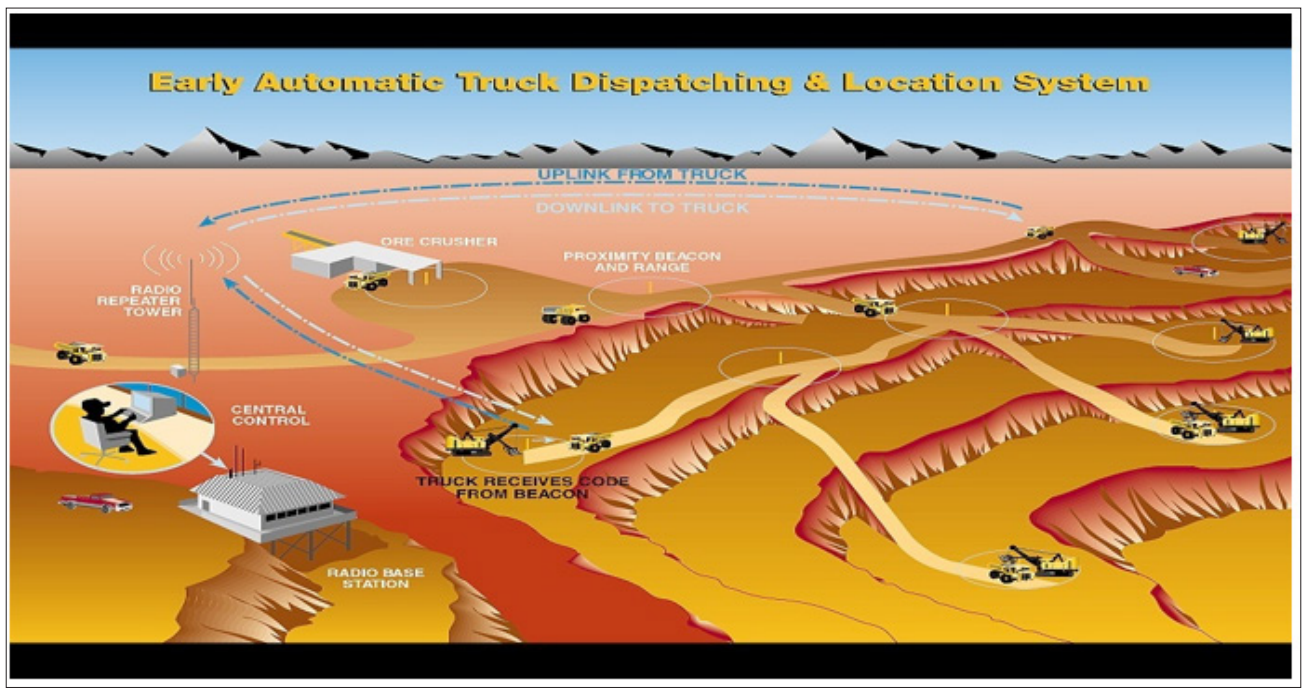

Figure 11: Truck dispatch system.

\section{Conclusion}

Rampura Aghucha being a SEDEX-type of deposit is a complex deposit in terms of geo-metallurgical characteristics. Slope stability accidents are one of the leading causes of fatalities in any surface mining operations [30]. It has become an important component in planning deeper mines and to help in mitigating hazardous 
problem due to rock failures. The study basically aims to allow safe and economic mining and to incorporate geotechnical complexity parameters and mechanical properties like porosity, swelling, and moisture content, degree of saturation, anisotropy, durability, elasticity, and plasticity. Various geotechnical parameters is being analyzed using Slope Stability Radar (SSR), Inclinometer, prism, rock bolting, rock stitching to supervise contrasting geological parameters in mines. The SSR provides broad area coverage of wall movements through rain, dust and smoke and the concurrent display of the movement of mine walls have allowed safely critical monitoring and continuous management of the risk of slope instability at a mine operations level. It is also believed to contribute significantly to safety and design of mines by providing accurate, reliable deformation data to further develop our understanding and analysis of failure mechanisms in open pit mines; eventually leading to improved slope design. It is also important in improving the actual metallurgical performance of the mines.

\section{References}

1. Roy AB, Kumar S, Laul V, Chauhan NK (2004) Tectonostratigraphy of the lead zinc bearing metasedimentary rocks of the Rampura Aghucha Mines and its neighbourhood, District, Bhilwara, Rajasthan, Implication on Metallogeny, Sediment hosted Lead Zinc Sulphide Deposits, Narosa Publishing House, New Delhi, India.

2. Gupta SN, Arora YK, Mathur RK, Iqballuddin Prasad B, Sahai TN, et al. (1980) Lithostratigraphic map of Aravalli region, southern Rajasthan and northeastern Gujarat (1: 1,000,000). Geological Survey of India, Hyderabad, India.

3. Gupta SN, Arora YK, Mathur RK, Prasad B, Sahai TN, et al. (1997) The Precambrian geology of the Aravalli Region. Memoir of the Geological Survey of India 123: 262.

4. Menzie WD, Mosier DL (1986) Grade and tonnage model of sedimentary exhalative Zn-Pb. In: Cox DP, Singer DA (Eds.), Mineral Deposit Models, United States Geological Survey Bulletin 1693: 212-215.

5. Vishwanath U, Prasad KS, Joshi A (2006) Geo-metallurgical studies of Rampura Agucha Deposit. Proceedings of the International Seminar on Mineral Processing Technology, Chennai, India. pp. 134-143.

6. Deb M, Sarkar SC (1990) Proterozoic tectonic evolution and metallogenesis in the Aravalli Delhi orogenic complex, Northwestern India. Precambrian Research 46(1-2): 115-137.

7. Deb M (1982) Rare minerals in rajpura-dariba ores-some further comments. Journal of Geological Society of India 23(5): 253-260.

8. Deb M, Kumar R (1982) The volcano-sedimentary environment of rajpura-dariba polymetallic ore deposit, udaipur district, Rajasthan. Geological Survey of India, Symposium on Metallogeny of the Precambrian, IGCP Project 91: 1-17.

9. Naha K, Majumdar A (1971) Reinterpretation of the aravalli basal conglomerate at morchana, udaipur district, Rajasthan, Western India. Geological Magazine 108: 111-114.

10. Naha K, Halyburton RV (1974) Early precambrian stratigraphy of central and southern Rajasthan, India. Precambrian Research 1(1): 55-73.

11. Poddar BC (1974) Evolution of sedimentary sulphide rhythmites into metamorphic tectonites in the base metal deposits of Rajpura-Dariba, Rajasthan. Quarterly Journal of Geological Mineral Metamorphic Society of India $46: 207-221$.

12. Raja Rao CS (1970) Sequence, structure and correlation of the metasediments and genesis of the banded gniessic complex of Rajasthan. Record of Geological Survey of India 98: 122-131.

13. Ranawat (1988) Metamorphic character of Rampura-Agucha Pb-Zn deposit, Rajasthan. Memoir Geological Society India 7: 397-409.

14. Sharma RS (1988) Patterns of metamorphism in the precambrian rocks of the Aravalli Mountain Belt. Geological Society of India Memoir 7: 3375.

15. Sinha Roy S (1984) Precambrian crustal interaction in Rajasthan, NW India. Proceeding Seminar on Crustal Evolution of Indian Shield and Its Bearing on Metallogeny, Indian Journal of Earth Sciences. pp. 84-91.

16. Roy AB, Jakhar SR (2002) Geology of Rajasthan (Northwest India) Precambrian to recent. Scientific Publishers, India.

17. Heron AM (1953) Geology of Central Rajasthan. Mem Geol Surv, India. p. 339.

18. Roy AB (1988) Stratigraphic and tectonic framework of the Aravalli Mountain Range. In: Roy AB (Ed.), Precambrian of the Aravalli Mountain, Rajasthan, India. pp. 3-31.

19. Sitharam TG, Hegde A (2017) Stability analysis of rock-fill tailing dam: An Indian case study. International Journal of Geotechnical Engineering 11(4): 332-342.

20. Roy AB, Kroner A (1996) Single zircon evaporation ages constraining the growth of the Archaean Aravalli Craton, Northwestern Indian shield. Geological Magazine 133(3): 333-342.

21. Wiedenbeck M, Goswami JN, Roy AB (1996) Stabilization of the Aravalli Craton of the Northwestern India at $2.5 \mathrm{Ga}$ : An ion microprobe zircon study. Chemical Geology 129(3-4): 325-340.

22. Sharma KK (2003) The Neoproterozoic malani magmatism, northwestern Indian shield, India.

23. Deb M (1999) Metallic mineral deposits of Rajasthan. In: Kataria P (Ed.), Proceedings Seminar on Geology of Rajasthan-Status and Perspective. M L Sukhadia University, Udaipur, India. pp. 213-237.

24. Hazarika P, Upadhyay D, Mishra B (2013) Contrasting geochronological evolution of the Rajpura-Dariba and Rampura-Agucha metamorphosed $\mathrm{Zn}-\mathrm{Pb}$ deposit, Aravalli-Delhi Belt, India. Journal of Asian Earth Sciences 73: 429-439.

25. Alam J, Siddiquie FN, Mohd S (2015) Petrographic studies of Pb-Zn ore deposits of Rajpura-Dariba-Bethumni belt in District Udaipur (Rajasthan) India. International Journal of Geosciences 6(4): 402-412.

26. Jain J, Bishnoi B, Vijayvargiya P, Gehlot H (2010) Practical training report. Rampura Aghucha Mines, India.

27. Cała M, Jakóbczyk J, Cyran K (2016) Inclinometer monitoring system for stability analysis: The western slope of the Bełchatów field case study. Studia Geotechnica et Mechanica 38(2): 1-13.

28. Poggiolini D (2005) Slope stability-Australian technology helps African mines manage risk, African Mining. pp.36-39.

29. Harries N, Noon D, Rowley K (2013) Case studies of slope stability radar used in open cut mines. The South African Institute of Mining and Metallurgy, International Symposium on Stability of Rock Slopes. pp.335-342.

30. JM Girard, EL McHugh (2002) Mining Publication: Detecting Problems with Mine Slope Stability. 